\title{
Characterization of primary biogenic aerosol particles in urban, rural, and high-alpine air by DNA sequence and restriction fragment analysis of ribosomal RNA genes
}

\author{
V. R. Després ${ }^{1,3}$, J. F. Nowoisky ${ }^{1,4}$, M. Klose ${ }^{2}$, R. Conrad ${ }^{2}$, M. O. Andreae ${ }^{1}$, and U. Pöschl ${ }^{1}$ \\ ${ }^{1}$ Biogeochemistry Department, Max Planck Institute for Chemistry, Becherweg 27, 55128 Mainz, Germany \\ ${ }^{2}$ Biogeochemistry Department, Max Planck Institute for Terrestrial Microbiology, Karl-von-Frisch-Straße, 35043 Marburg, \\ Germany \\ ${ }^{3}$ Department of General Botany, Johannes Gutenberg University, Saarstraße 1, 55099 Mainz, Germany \\ ${ }^{4}$ Department of Geosciences, Johannes Gutenberg University, Becherweg 14, 55128 Mainz, Germany
}

Received: 24 January 2007 - Published in Biogeosciences Discuss.: 5 February 2007

Revised: 13 November 2007 - Accepted: 29 November 2007 - Published: 20 December 2007

\begin{abstract}
This study explores the applicability of DNA analyses for the characterization of primary biogenic aerosol (PBA) particles in the atmosphere. Samples of fine particulate matter $\left(\mathrm{PM}_{2.5}\right)$ and total suspended particulates (TSP) have been collected on different types of filter materials at urban, rural, and high-alpine locations along an altitude transect in the south of Germany (Munich, Hohenpeissenberg, Mt. Zugspitze).
\end{abstract}

From filter segments loaded with about one milligram of air particulate matter, DNA could be extracted and DNA sequences could be determined for bacteria, fungi, plants and animals. Sequence analyses were used to determine the identity of biological organisms, and terminal restriction fragment length polymorphism analyses (T-RFLP) were applied to estimate diversities and relative abundances of bacteria. Investigations of blank and background samples showed that filter materials have to be decontaminated prior to use, and that the sampling and handling procedures have to be carefully controlled to avoid artifacts in the analyses.

Mass fractions of DNA in $\mathrm{PM}_{2.5}$ were found to be around $0.05 \%$ in urban, rural, and high-alpine aerosols. The average concentration of DNA determined for urban air was on the order of $\sim 7 \mathrm{ng} \mathrm{m}^{-3}$, indicating that human adults may inhale about one microgram of DNA per day (corresponding to $\sim 10^{8}$ haploid bacterial genomes or $\sim 10^{5}$ haploid human genomes, respectively).

Most of the bacterial sequences found in $\mathrm{PM}_{2.5}$ were from Proteobacteria (42) and some from Actinobacteria (10) and Firmicutes (1). The fungal sequences were characteristic for Ascomycota (3) and Basidiomycota (1), which are known to actively discharge spores into the atmosphere. The plant

Correspondence to: V. R. Després

(despres@mpch-mainz.mpg.de) sequences could be attributed to green plants (2) and moss spores (2), while animal DNA was found only for one unicellular eukaryote (protist).

Over $80 \%$ of the 53 bacterial sequences could be matched to one of the $19 \mathrm{~T}-\mathrm{RF}$ peaks found in the $\mathrm{PM}_{2.5}$ samples, but only $40 \%$ of the T-RF peaks did correspond to one of the detected bacterial sequences. The results demonstrate that the T-RFLP analysis covered more of the bacterial diversity than the sequence analysis. Shannon-Weaver indices calculated from both sequence and T-RFLP data indicate that the bacterial diversity in the rural samples was higher than in the urban and alpine samples. Two of the bacterial sequences (Gammaproteobacteria) and five of the T-RF peaks were found at all sampling locations.

\section{Introduction}

Biogenic aerosols are ubiquitous in the Earth's atmosphere, where they influence atmospheric chemistry and physics, the biosphere, climate, and public health. They play an important role in the spread of biological organisms and reproductive materials, and they can cause or enhance human, animal, and plant diseases. Moreover, they influence the Earth's energy budget by scattering and absorbing radiation, and they can initiate the formation of cloud droplets and precipitation as cloud condensation and ice nuclei (Dingle, 1966; Schnell and Vali, 1972; Cox and Wathes, 1995; Andreae and Crutzen, 1997; Pruppacher and Klett, 1997; Hamilton and Lenton, 1998; Andreae et al., 2002; Mikhailov et al., 2004; Taylor and Jonsson, 2004; Jaenicke, 2005; Kanakidou et al., 2005; Lohmann and Feichter, 2005; Pöschl, 2005; Dusek et al., 2006; Fuzzi et al., 2006; Hakola et al., 2006; Kloster et al.,

Published by Copernicus Publications on behalf of the European Geosciences Union. 
2006; McFiggans et al., 2006; Sun and Ariya, 2006; Möhler et al., 2007; Hock et al., 2007).

Primary biogenic aerosol (PBA) particles and components are emitted directly from the biosphere to the atmosphere. PBA particles range in size from millimeters down to tens of nanometers, and may thus be much smaller than originally thought (Jaenicke, 2005). Particles of biological origin, like pollen, bacteria, spores, viruses, plant and animal fragments (e.g., dandruffs, skin fragments), are all within this size range (Simoneit and Mazurek, 1982; Matthias-Maser and Jaenicke, 1994; Artaxo, 1995; Bauer et al., 2005; Ahern et al., 2007; Elster et al., 2007; Zhang et al., 2007). The actual abundance and origin of biogenic aerosol particles and components are, however, still poorly understood and quantified.

Compared to conventional methods of PBA analysis (microscopy, protein staining, cultivation of microorganisms, etc.), DNA analyses can provide much more information. They enable the identification and characterization of cultured and uncultured microorganisms (90 to $99 \%$ of fungi and bacteria presently cannot be cultured in the laboratory; Amann et al., 1995), of viable and dead cells, and of plant and animal fragments.

The polymerase chain reaction (PCR) enables very efficient amplification of characteristic regions of deoxyribonucleic acid (DNA), which can be analyzed, e.g., by sequencing and terminal restriction fragment length polymorphism analysis (T-RFLP), and identified by comparison with genetic databanks. Even minute amounts of DNA - as little as one molecule - are sufficient to identify biological organisms and materials. The high sensitivity of this technique, however, also bears the risk of amplifying trace amounts of DNA with which the investigated aerosol sample or the sampling material (filters, impaction foils, etc.) may have been contaminated in the course of material production, aerosol sampling, sample transport, storage, and analysis. Furthermore, longterm storage of samples can lead to chemical modification and degradation of DNA. Contamination and degradation effects can lead to substantial analytical artifacts and loss of information.

Depending on the genomic region that is sequenced, organisms can be identified to the domain, class, order, family, genus or even species level. Regions commonly used for taxonomic identification are the ribosomal RNA genes. These are the 16S ribosomal genes in the domains Archaea and Bacteria, and the $18 \mathrm{~S}$ ribosomal genes in the domain $E u$ karya (animals and plants). For eukaryotic fungi usually the internal transcribed spacer (ITS) region, which is localized between the $18 \mathrm{~S}, 5 \mathrm{~S}$ and $28 \mathrm{~S}$ regions, is used for the taxonomic identification. All these gene sequences are useful, because they exhibit both conserved regions for the binding of universal primer pairs and variable regions that are characteristic for different groups or individual species of biological organisms. For plants, the ribulose-1,5-bisphosphate carboxylase/oxygenase large subunit gene (rbcL) in the chloroplast genome provides additional taxonomic information
(Vilgalys and Hester, 1990; Weisburg et al., 1991; Gardes and Bruns, 1993; Whiting et al., 1997; Little and Barrington, 2003; Fierer et al., 2005). For bacteria and archaea, T-RFLP analysis provides information about the diversity and relative abundance, which is complementary to the information obtained by the analysis and blasting of DNA sequences (Liu et al., 1997; Lukow et al., 2000).

First applications of molecular genetic techniques for the analysis of PBA have been reported only recently. These studies had been focused on the sequence analysis of DNA from specific groups of organisms, mostly from bacteria or fungi collected at one or two sampling locations (Radosevich et al., 2002; Boreson et al., 2004; Hughes et al., 2004; Maron et al., 2005; Kuske et al., 2006; Brodie et al., 2007). In the present study we combine sequence analyses of different groups of organisms (bacteria, archaea, fungi, plants, animals) with T-RFLP investigations and DNA quantification in urban, rural, and high-alpine aerosol samples. Moreover, we investigate potential contamination problems, which have not been addressed in earlier publications. This pilot study has been limited to a set of exemplary samples, and the measurement results should not be over-interpreted with regard to the spatial and temporal variability of PBA. Nevertheless, they shall serve for orientation and planning of more comprehensive future investigations of PBA by DNA analysis.

\section{Material and methods}

\subsection{Filter samples}

Samples were collected on three different filter types (glass fiber, cellulose nitrate, and polypropylene) from urban, rural and high-alpine air at five different locations in Southern Germany, as detailed below and summarized in Table 1. Fine air particulate matter $\left(\mathrm{PM}_{2.5}\right.$; aerodynamic diameter $\left.<2.5 \mu \mathrm{m}\right)$ was collected on glass fiber filters $(15 \mathrm{~cm}$ diameter, $\mathrm{MN}$ 85/90 binder-free, Macherey-Nagel, Düren, Germany) using a stand-alone high-volume filter sampler (HVFS, Digitel DHA-80, Riemer, Hausen, Germany; sample air flow $500 \mathrm{~L} \mathrm{~min}^{-1}$; sampling time 4 to 5 days). For decontamination (removal of organic compounds), the glass fiber filters were baked in a muffle furnace at $300^{\circ} \mathrm{C}$ for $12 \mathrm{~h}$ prior to use. The mass of particulate matter collected on each filter was determined by weighing the filter before and after sampling (Schauer et al., 2004) and the samples were stored at $-20^{\circ} \mathrm{C}$. Urban $\mathrm{PM}_{2.5}$ samples were collected by the IWC (Institute of Hydrochemistry, Technical University of Munich, Munich-Grosshadern) on the campus of the University Hospital Grosshadern in the southwestern outskirts of $\mathrm{Mu}-$ nich at $550 \mathrm{~m}$ above sea level (a.s.l.). The HVFS was positioned on a lawn in the front yard of the Institute building, about ten meters away from a minor on-campus road and several hundred meters away from the nearest parking lots and city roads. Rural $\mathrm{PM}_{2.5}$ samples were collected at 
Table 1. Investigated filter samples of fine particulate matter $\left(\mathrm{PM}_{2.5}\right)$. The sample ID specifies the sampling location: U=urban, Munich; $\mathrm{R}=$ rural, Hohenpeissenberg; HA=high-alpine, Zugspitze. The sampled air volume is normalized to standard temperature and pressure (STP; $0^{\circ} \mathrm{C}, 1013 \mathrm{hPa}$ ). The mass collected on the filter, the corresponding concentration in the sampled air volume, and mass fractions are given for particulate matter (PM) and DNA. In addition information on the total number of sequences, number of different measured sequences, the total number of detected T-RF peaks as well as the number and position of T-RF peaks corresponding to identified sequences per filter is given.

\begin{tabular}{|c|c|c|c|c|c|c|c|c|c|c|c|}
\hline Sample ID & Sampling period & $\begin{array}{c}\text { Air Volume } \\
\left(\mathrm{m}^{3}\right)\end{array}$ & $\begin{array}{l}\text { PM mass } \\
\text { (mg) }\end{array}$ & $\begin{array}{l}\text { PM conc. } \\
\left(\mu \mathrm{g} / \mathrm{m}^{3}\right)\end{array}$ & $\begin{array}{l}\text { DNA mass } \\
\qquad(\mu \mathrm{g})\end{array}$ & $\begin{array}{l}\text { DNA conc. } \\
\left(\mathrm{ng} / \mathrm{m}^{3}\right)\end{array}$ & $\begin{array}{l}\text { DNA / PM } \\
(\mu \mathrm{g} / \mathrm{mg})\end{array}$ & $\begin{array}{l}\text { Total Number of } \\
\text { sequences } \\
\text { (incl. plants etc.) }\end{array}$ & $\begin{array}{l}\text { Number of } \\
\text { different } \\
\text { sequences }\end{array}$ & $\begin{array}{l}\text { Total Number } \\
\text { of T-RFs }\end{array}$ & $\begin{array}{l}\text { Number of T-RFs } \\
\text { corresp. to } \\
\text { sequences }\end{array}$ \\
\hline U-A1 & $18.02 .05-22.02 .05$ & 2617.8 & 61.6 & 23.5 & 21.6 & 9.0 & 0.35 & 3 & 3 & 7 & $2(158,493)$ \\
\hline U-A2 & $26.02 .05-02.03 .05$ & 2651.8 & 62.2 & 23.4 & 20.8 & 8.0 & 0.33 & 6 & 5 & 6 & $3(152,493,494)$ \\
\hline U-A3 & $22.03 .05-26.03 .05$ & 2582.4 & 64.8 & 25.1 & 24.8 & 9.8 & 0.39 & 9 & 6 & 6 & $2(493,494)$ \\
\hline U-A4 & $17.05 .05-21.05 .05$ & 2589.0 & 25.9 & 10.0 & 6.4 & 2.8 & 0.25 & 9 & 9 & 6 & $2(493,494)$ \\
\hline U-A5 & 17.05 .05 & n.d. & n.d. & n.d. & 1.6 & n.d. & n.d. & 6 & 6 & 4 & $2(158,489)$ \\
\hline R-A10 & 02.06 .04 & n.d. & n.d. & n.d. & 4.8 & n.d. & n.d. & 2 & 2 & 7 & $1(58)$ \\
\hline R-A11 & $02.06 .04-07.06 .04$ & 3167.8 & 23.0 & 7.1 & 8.8 & 3.1 & 0.4 & 3 & 3 & 3 & $1(493)$ \\
\hline R-A12 & $17.06 .04-22.06 .04$ & 3146.2 & 15.9 & 5.1 & 8.8 & 3.1 & 0.55 & 5 & 3 & 5 & $2(71,489)$ \\
\hline R-A13 & $16.08 .04-21.08 .04$ & 3028.8 & 15.1 & 5.0 & 4.8 & 1.7 & 0.32 & 2 & 2 & 6 & $1(493)$ \\
\hline R-A14 & $31.08 .04-05.09 .04$ & 3126.4 & 30.1 & 9.6 & 12.0 & 4.2 & 0.4 & 4 & 3 & 7 & $1(494)$ \\
\hline HA-A6 & $13.09 .03-17.09 .03$ & 2269.1 & 4.4 & 1.9 & 7.2 & 3.5 & 1.65 & 3 & 3 & 4 & 0 \\
\hline HA-A7 & $17.09 .03-21.09 .03$ & 2243.3 & 13.0 & 5.8 & 6.4 & 3.5 & 0.5 & 3 & 3 & 4 & $1(493)$ \\
\hline HA-A8 & $21.09 .03-25.09 .03$ & 2272.0 & 14.7 & 6.5 & 7.2 & 3.7 & 0.49 & 6 & 6 & 4 & $2(493,494)$ \\
\hline HA-A9 & 21.09 .03 & n.d. & n.d. & n.d. & 2.4 & n.d. & n.d. & 1 & 1 & 4 & $1(493)$ \\
\hline
\end{tabular}

the Meteorological Observatory Hohenpeissenberg (MOHp), which is located on top of a small mountain $(990 \mathrm{~m}$ a.s.l., 200-300 $\mathrm{m}$ higher than the surrounding terrain) about halfway between Munich and Mt. Zugspitze. The HVFS was positioned on an open platform on top of the meteorological observatory. High-alpine $\mathrm{PM}_{2.5}$ samples were collected at the Environmental Research Station Schneefernerhaus, Zugspitze (UFS). The sampling site ( $2650 \mathrm{~m}$ a.s.l.) was located on the southern slope close to the summit of Mt. Zugspitze (2962 ma.s.l.) at the northern edge of the Alps. The HVFS was located on the south-western platform on top of the research station.

Samples of total suspended particles (TSP) on polypropylene filters $\left(44 \times 44 \mathrm{~cm}^{2}\right)$ were provided by the Institute of Radiation Protection, GSF-National Research Center for Environment and Health, Neuherberg. The samples were collected with a high-volume air sampler (ASS - 500 Central Laboratory for Radiological Protection, Warsaw, Poland, PTI Ulf Fischer, Erlangen) situated on the east side of the GSF Campus in Munich, next to one of the biggest dry lawns in southern Bavaria (sample air flow $700 \mathrm{~L} \mathrm{~h}^{-1}$; sampling time $10 \mathrm{~d})$. TSP samples on cellulose nitrate membrane filters $(15 \mathrm{~cm}$ diameter, Schleicher and Schüll) were provided by the Forschungszentrum Karlsruhe $\mathrm{GmbH}$, Institut für Meteorologie und Klimaforschung, IMK-IFU. They were collected with a filter sampler (Digitel DHA-80) at the summit of Mt. Zugspitze (2962 m a.s.l.; air sample volume $1181 \mathrm{~L}$; sampling time $24 \mathrm{~h}$ ). After sampling the filters were compressed into compact tablets and used for radionuclide measurements $\left({ }^{7} \mathrm{Be}\right.$ and ${ }^{210} \mathrm{~Pb}$ activity on Mt. Zugspitze TSP filter, while $\gamma$-spectrometry on Munich TSP filter). The TSP filter substrates had not been decontaminated prior to use, and the samples were stored at room temperature because they had originally not been foreseen for molecular genetic analysis.

\subsection{DNA extraction and quantification}

$\mathrm{PM}_{2.5}$ filter sample pieces $(0.5 \times 1 \mathrm{~cm}, \sim 0.2 \mathrm{~g}$ filter loaded with $0.5-8 \mathrm{mg} \mathrm{PM} 2.5$ ) were lysed and extracted with a commercial soil DNA extraction kit (LysingMatrixE, Fast DNA Spin Kit, Biomedicals) according to the supplier's instructions with the following modifications: 10-min centrifugation step after the lysis, additional $900 \mu$ l buffer, and repeated beating and centrifugation. Both generated supernatants were combined for the further extraction process. Finally, the DNA was dissolved in $100 \mu 1$ elution buffer, and the DNA concentration was measured by UV spectrophotometry at $260 \mathrm{~nm}$.

The other filter samples were extracted with the same kit and procedures, except for extracting twice with $400 \mu \mathrm{l}$ sodium phosphate buffer.

\subsection{DNA amplification}

PCRs were performed for T-RFLP and sequence analyses (1-5 $\mu 1$ sample extract used as template DNA). The reaction mixtures always contained ca. $18 \mathrm{ng}_{\mu \mathrm{l}^{-1}}$ template DNA, $1 \times \mathrm{PCR}$ buffer, $1.5 \mathrm{mM} \mathrm{MgCl}_{2}, 0.2 \mathrm{mM}$ deoxynucleoside triphosphate (dNTPs) (MP Biomedicals), $0.33 \mu \mathrm{M}$ of each primer (MWG-Biotech, Ebersberg, Germany), $10 \mu \mathrm{g}$ BSA and $5 \mathrm{U}$ of Taq DNA polymerase (Invitrogen, Netherlands).

PCRs for sequence analyses of bacteria, archaea, fungi, plants and animals were performed with the primer pairs listed in Table 2 under the following experimental conditions: $50 \mu \mathrm{l}$ reaction volume (thermal cycler model 2400, PE Applied Biosystems or PTC 200/225, MJ Research); thermal profile: initial denaturing at $94^{\circ} \mathrm{C}$ for $3 \mathrm{~min}$; 35 cycles with denaturing at $94^{\circ} \mathrm{C}$ for $30 \mathrm{~s}$, annealing at primer pair specific temperature for $30 \mathrm{~s}$, and elongation at $72^{\circ} \mathrm{C}$ for $30 \mathrm{~s}$; final extension step at $72^{\circ} \mathrm{C}$ for $5 \mathrm{~min}$. The specific annealing 
Table 2. Polymerase chain reaction (PCR) primer information. Sequences of the forward and reverse primers are listed with target locations, product lengths, annealing temperatures, and literature references.

\begin{tabular}{|c|c|c|c|c|c|c|}
\hline Organism & Forward primer & Reverse Primer & Gene & $\begin{array}{l}\text { Product } \\
\text { length }\end{array}$ & $\begin{array}{l}\text { Annealing } \\
\text { temperature }\end{array}$ & Reference \\
\hline Bacteria & 9/27f: $5^{\prime}$ gag ttt gat c(ac)t ggc tca g $3^{\prime}$ & 1492r: $5^{\prime}$ acg g(ct)t acc ttg tta cga ctt $3^{\prime}$ & $16 \mathrm{~S}$ (nuclear) & $1564 \mathrm{bp}$ & $57^{\circ} \mathrm{C}$ & (Weisburg et al., 1991) \\
\hline Archaea & 109f: $5^{\prime}$ ac (gt) gct cag taa cac gt $3^{\prime}$ & 934r: $5^{\prime}$ gtg ctc cec cgc caa ttc ct $3^{\prime}$ & $16 \mathrm{~S}$ (nuclear) & 825 bp & $52^{\circ} \mathrm{C}$ & (Großkopf, 1998) \\
\hline Fungi & $5.8 \mathrm{~s}: 5^{\prime} \mathrm{cgctgc} \mathrm{gtt} \mathrm{ctt} \operatorname{cat} \operatorname{cg} 3^{\prime}$ & ITSf: $5^{\prime}$ tcc gta ggt gaa cet gcg g $3^{\prime}$ & ITS (nuclear) & $\sim 300 \mathrm{bp}$ & $55^{\circ} \mathrm{C}$ & $\begin{array}{l}\text { (Vilgalys and Hester, 1990; } \\
\text { Gardes and Bruns, 1993; } \\
\text { Fierer et al., 2005) }\end{array}$ \\
\hline Plants & F1F: $5^{\prime}$ atg tca cca caa aca gaa act aaa gca agt $3^{\prime}$ & F1379R: $5^{\prime}$ tca caa gca gca gct agt tca gga ctc $3^{\prime}$ & rbcL (chloroplast) & $1392 \mathrm{bp}$ & $57^{\circ} \mathrm{C}$ & (Little and Barrington, 2003) \\
\hline Animals & 18Sai_f: $5^{\prime}$ cet gag aaa cgg cta cca cat c $3^{\prime}$ & 18Sbi_r: $5^{\prime}$ gag tct cgt tcg tta tcg ga $3^{\prime}$ & 18S (nuclear) & $1140 \mathrm{bp}$ & $55^{\circ} \mathrm{C}$ & (Whiting et al., 1997) \\
\hline
\end{tabular}

temperatures for the different primer pairs were determined in temperature gradient experiments (Table 2).

PCRs for T-RFLP were carried out using a carboxyfluorescein (fam)-labeled oligonucleotide primer and an unlabelled primer (MWG, Ebersberg). For bacteria we used $9 / 27 \mathrm{f}$ (fam) 5'-GAG TTT GAT C(AC)T GGC TCA G-3' and 907 / 926r 5'-CCG TCA ATT C(AC)T TTR AGT TT-3', which amplify 16S rRNA genes (Weisburg et al., 1991). For archaea we used 109f 5'-AC(GT) GCT CAG TAA CAC GT-3' and 934r (fam) 5'-GTG CTC CCC CGC CAA TTC CT-3' (Großkopf et al., 1998).

The thermal profile of the T-RFLP-PCR for bacteria was as follows: $94^{\circ} \mathrm{C}$ for $3 \mathrm{~min} ; 35$ cycles each with $45 \mathrm{~s}$ at $94^{\circ} \mathrm{C}$, $30 \mathrm{~s}$ at $57^{\circ} \mathrm{C}$, and $80 \mathrm{~s}$ at $72^{\circ} \mathrm{C} ; 5 \mathrm{~min}$ at $72^{\circ} \mathrm{C}$. PCR products were separated by electrophoresis $(80 \mathrm{~V}$ to $120 \mathrm{~V})$ on a 1 to $1.5 \%$ agarose gel and visualized by ethidium bromide staining. The amplification of archaea for the T-RFLP analysis was performed with the same thermal profile, except that the annealing step at $52^{\circ} \mathrm{C}$ lasted $45 \mathrm{~s}$, elongation at $72^{\circ} \mathrm{C} 90 \mathrm{~s}$ and denaturing again $30 \mathrm{~s}$ at $94^{\circ} \mathrm{C}$.

\subsection{T-RFLP analysis}

PCR products for T-RFLP were purified using the GenElute PCR clean up kit (Sigma-Aldrich Chemie GmbH, Taufkirchen). Approximately $100 \mathrm{ng}$ of the amplicons were digested $\left(3 \mathrm{~h}, 37^{\circ} \mathrm{C}\right.$, total volume $\left.10 \mu \mathrm{l}\right)$ with $5 \mathrm{U}$ of the restriction endonuclease MspI (bacteria) or TaqI (archaea) (Fermentas). Aliquots $(1.25 \mu \mathrm{l})$ of the digested amplicons were mixed with $0.85 \mu 1$ of formamide and $0.4 \mu 1$ of an internal lane standard (GeneScan-1000 ROX; PE Applied Biosystems, Darmstadt), denatured at $94^{\circ} \mathrm{C}$ for 2 min and then chilled on ice. Electrophoresis was performed on a polyacrylamide gel (automated DNA sequencer model 373; PE Applied Biosystems, Darmstadt) for $6 \mathrm{~h}$ at the following settings: $2500 \mathrm{~V}, 40 \mathrm{~mA}$, and $27 \mathrm{~W}(24 \mathrm{~cm}$ gel length). After electrophoresis, the lengths (peak positions) of the terminal restriction fragments (T-RFs) and the intensities (peak areas) of their fluorescence emission signals were automatically calculated by the GeneScan Analysis software, version 2.1 (PE Applied Biosystems, Darmstadt).

For each of the 14 filter samples the sum of all measured peak heights of the T-RF fragments (50-928 bp) was calculated. Every peak was normalized by division through the peak-height sum of its sample and multiplication with the smallest peak-height sum of all samples. Normalized peak heights and normalized peak-height sums were then used to calculate relative abundances of the T-RF peaks for the different samples and locations (Lüdemann et al., 2000).

\subsection{Cloning and sequencing}

Amplification products for sequencing were cloned into $E s$ cherichia coli using the TOPO TA Cloning ${ }^{T M}$ Kit (Invitrogen, Netherlands) following the supplier's instructions. The cells of E.coli were transformed by heat-shock for $30 \mathrm{~s}$ at $42^{\circ} \mathrm{C}$ and cultivated on LB plates containing ampicillin and $\mathrm{X}-\mathrm{Gal}$ at $37^{\circ} \mathrm{C}$ for approximately $16 \mathrm{~h}$. Colonies containing inserts were identified by blue-white selection and lysed in $20 \mu \mathrm{l}$ water for $10 \mathrm{~min}$ at $95^{\circ} \mathrm{C}$. The inserts of 24 colonies were amplified using $3 \mu 1$ lysate in a $40 \mu 1$ reaction (PCR master mix: $2.5 \mathrm{mM} \mathrm{MgCl}_{2}, 1 \times$ PCR Buffer, $250 \mathrm{nM}$ of each primer, $250 \mu \mathrm{M}$ of each dNTP, $1.25 \mathrm{U}$ Taq (Invitrogen, Netherlands)). The only primer pair used in these PCRs was M13F-40 and M13R, and the temperature programme was as follows: $94^{\circ} \mathrm{C}$ for $5 \mathrm{~min} ; 40$ cycles at $93^{\circ} \mathrm{C}$ for $30 \mathrm{~s}$, $55^{\circ} \mathrm{C}$ for $1 \mathrm{~min}$, and $72^{\circ} \mathrm{C}$ for $1 \mathrm{~min}$; final extension step at $72^{\circ} \mathrm{C}$ for $15 \mathrm{~min}$. DNA sequences were determined with ABI Prism 377, 3100, and 3730 sequencers (Applied Biosystems, Darmstadt) using BigDye-terminator v3.1 chemistry at the DNA Core Facility of the Max Planck Institute for Plant Breeding Research.

The measured sequences were aligned using the program BioEdit (BioEdit 7.05; http://www.mbio.ncsu.edu/BioEdit/ bioedit.html). For comparison with known sequences, databank queries using the Basic Local Alignment Search Tool (BLAST) were performed via the website of the National Center for Biotechnology Information (NCBI, http://www. ncbi.nlm.nih.gov/). For each of the measured sequences, the 
first hit in the list of databank search results was taken as the "best-match sequence". The degree of accordance (identity) and accession number of the best-match sequences were recorded and are presented below.

\subsection{Inhibition tests}

To test inhibitory effects of components (extracted in association with the DNA) within the filter extract on the DNA amplification process, an artificial vector pET44a was used as a DNA template (20 ng) to amplify a 2004 bp long product with the forward primer T7 $5^{\prime}$-TAA TAC GAC TCA TCA CTA TAG GG $-3^{\prime}$ and the reverse primer pET44rev $5^{\prime}$-TAC GGC GTT TCA CTT CTG A-3' (Nowoisky, 2005). The PCR $(50 \mu \mathrm{l})$ was performed as described above. The PCR program was: $94^{\circ} \mathrm{C}$ for $3 \mathrm{~min}, 35$ cycles of $94^{\circ} \mathrm{C}$ for $30 \mathrm{sec}, 55^{\circ} \mathrm{C}$ for $30 \mathrm{sec}$ and $72^{\circ} \mathrm{C}$ for $1.5 \mathrm{~min}$. The final elongation step was $72^{\circ} \mathrm{C}$ for $7 \mathrm{~min}$.

The degree of inhibition a DNA extract causes was estimated by adding $1 \mu 1$ of this extract to a PCR master mix containing the pET44a vector. After PCR and gel electrophoresis, inhibition effects were detected by optical inspection of the gel and comparison to a positive vector control. Bands that were less bright than the vector control were assumed to indicate partial inhibition. Missing bands were assumed to indicate complete inhibition. This inhibition test was performed for one urban $\mathrm{PM}_{2.5}$ DNA extract. The brightness of the band was reduced about $50 \%$ compared to the vector control.

Additonal tests were performed with a polypropylene filter TSP sample (TSP-U-5) and with a cellulose nitrate TSP sample (TSP-HA-12). For each sample, a 2-3 mm piece of the filter was added to the PCR mastermix, then the vector was added and the PCR and detection were performed as described above. The cellulose nitrate filter caused complete inhibition of the PCR reaction, and the polypropylene filter reduced the brightness of the amplified vector band by about $60 \%$ compared to the vector control.

\subsection{Phylogenetic analysis}

With the ARB programme (Ludwig et al., 2004) a phylogenetic analysis was performed for all bacterial sequences determined in this study. In this approach a parsimony tree was calculated using sequences provided by ARB. These sequences were calculated into a tree. Complete sequences, about 300 , which were closely related, were extracted and used to calculate a Neighbor-Joining tree. Into this NeighborJoining tree the sequences from this study were included without changing the topology of the tree. All sequences that added no information to the tree were excluded again without changing the topology of the tree.

\subsection{Statistical analysis}

For each of the $\mathrm{PM}_{2.5}$ sampling locations the sequence and T-RFLP data were used to calculate the ShannonWeaver diversity index $(H)$ and the evenness $(e)$ as follows: $\bar{H}=(C / N)\left(N * \log N-\sum n_{i} \log n_{i}\right)$, where $C$ is $2.3, N$ the total number of obtained sequences (peaks) at the sampling location, and $n_{i}$ the number of sequences (peaks) belonging to a certain group of bacteria (e.g., Gammaproteobacteria); $e=\bar{H} / S$, where $S$ is the number of bacterial groups (peaks) at the sampling location.

\section{Results and discussion}

\subsection{DNA Detection}

\subsubsection{Atmospheric aerosol samples}

A commercial soil DNA extraction kit was used to extract DNA from 28 filter samples of air particulate matter from urban, rural and high-alpine locations as detailed in Table 1. DNA was found in all extracts (2-38 ng $\mu \mathrm{l}^{-1}$ in $100 \mu \mathrm{l}$ ), which demonstrates that the extraction method is applicable for different aerosol filter types such as glass fiber, cellulose nitrate, and polypropylene filters (as well as a quartz fiber filter test sample).

The results show that DNA is present not only in coarse particles but also in fine particulate matter $\left(\mathrm{PM}_{2.5}\right.$, aerodynamic diameter $\leq 2.5 \mu \mathrm{m})$, and that small sample aliquots with small amounts of air particulate matter (0.5$8 \mathrm{mg} \mathrm{PM} \mathrm{PM}_{2.5}$ ) are sufficient to extract measurable amounts of DNA. Moreover, they show that DNA can be extracted not only from fresh samples, but also from samples that have been taken for other purposes and stored for extended periods of time (in the present case three years at $-20^{\circ} \mathrm{C}$ or one year at room temperature). DNA could be recovered even from the compact tablets into which the cellulose nitrate filters and polypropylene filters had been compressed and which had already been used for radionuclide measurements.

Nevertheless, DNA starts to degrade as soon as an organism dies. It breaks into smaller pieces and is chemically modified (Pääbo, 1989; Lindahl, 1993; Höss et al., 1996; Smith et al., 2001). Under cool, dark, and dry conditions DNA can be preserved for several thousand years (Pääbo et al., 2004), but the DNA amount decreases and DNA information is lost. Thus, air filter samples for molecular genetic analysis should be kept dry and frozen to slow down degradation processes.

From the DNA concentration in the sample extracts we calculated the equivalent mass of DNA per filter sample, the mass fraction of DNA in the sampled air particulate matter, and the concentration of DNA in the sampled air volume. Across sampling locations, the DNA concentrations in air varied in the range of $0.8-9.8 \mathrm{ng} \mathrm{m}^{-3}$. Among the $\mathrm{PM}_{2.5}$ glass fiber filters, the urban samples exhibited the highest DNA concentrations, with an average value of $7 \mathrm{ng} \mathrm{m}^{-3}$. The 


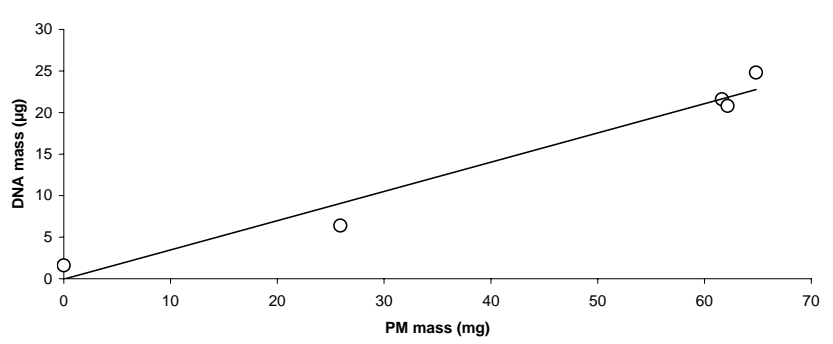

Fig. 1. DNA vs. PM mass in urban fine particulate matter $\left(\mathrm{PM}_{2.5}\right)$. Correlation between the mass of DNA and the total mass of particulate matter (PM) in samples collected in the city of Munich, Feb-May 2005; correlation coefficient 0.98 .

DNA mass fraction in urban $\mathrm{PM}_{2.5}$ was nearly constant at $\sim 0.03 \%$, which is confirmed and illustrated by the plot and linear trend $\left(r^{2}=0.98\right)$ of DNA vs. PM in Fig. 1. The observation of a high and near-constant relative abundance of DNA from biological particles in urban $\mathrm{PM}_{2.5}$ is consistent with the high mass fraction of proteins (up to $\sim 5 \%$ ) in the large set of samples, from which the filters investigated in this study were taken (Franze, 2004; Franze et al., 2005; Pöschl, 2005; Fehrenbach, 2006). The DNA/protein ratio of $\sim 1 / 100$ is also consistent with the typical proportions of DNA and proteins in living organisms (e.g., 1/15 in prokaryotes in Voet and Voet, 1995).

To put the abundance of DNA in fine, and thus respirable, air particulate matter into perspective with bacterial and human genomes, we have performed the following back-of-theenvelope calculations: Under the assumption of an average DNA concentration of $\sim 7 \mathrm{ng} \mathrm{m}^{-3}$, average DNA amounts of $\sim 4$ fg per haploid bacterial genome (E.coli) or $\sim 3$ pg DNA per haploid human genome, and adult human breathing rates between 5 and $120 \mathrm{~L} \mathrm{~min}^{-1}$ (sleep vs. sports), an adult person living in a city can be expected to inhale every day about $0.05-1.2 \mu \mathrm{g}$ DNA, corresponding to $10^{7}-10^{8}$ haploid bacterial genomes (E.coli) or $10^{4}-10^{5}$ haploid human genomes, respectively. The rural and high-alpine $\mathrm{PM}_{2.5}$ glass fiber filter samples exhibited lower PM and DNA concentrations, but similar or higher mass fractions of DNA $(0.03-0.16 \%)$, which are again consistent with high mass fractions of proteins observed in these and related samples (Franze, 2004; Franze et al., 2005; Fehrenbach, 2006). These findings confirm that DNA is not rapidly degraded in frozen glass fiber filter samples of air particulate matter.

The absolute and relative concentrations of DNA determined for the urban and high-alpine TSP samples collected on cellulose nitrate and polypropylene filters were generally lower than those determined for the $\mathrm{PM}_{2.5}$ glass fiber filters. This may be due to stronger inhibition effects (see Sect. 2.6) or faster degradation of DNA in the samples stored at room temperature. On the other hand, the TSP samples are likely to have been affected by elevated blank levels of DNA, because the filters had not been decontaminated prior to use (Sect. 3.1.2).

The above results are subject to uncertainties related to contamination, extraction efficiency, degradation, and photometric quantification of DNA. They certainly need to be corroborated by future investigations of larger sample numbers and complementary test experiments and measurement techniques. Nevertheless, we think that the observed trends, correlations, and orders of magnitude reported above provide a reasonable first estimate and basis for further comprehensive and systematic investigations of the abundance of DNA in air particulate matter. To our knowledge, no comparable measurement data on the abundance of DNA in air have been published yet.

\subsubsection{Blank and background samples}

In parallel to the filter samples of air particulate matter, four different types of blank and background samples have been investigated to check for possible sources of contamination: (1) six freshly pre-baked glass fiber filters ("glass fiber laboratory blank"); (2) a polypropylene filter freshly taken from the sealed original packing of the commercial supplier ("polypropylene supplier blank"); (3) a polypropylene filter pressed to a tablet but not exposed to air sampling ("polypropylene tablet blank"); (4) one pre-baked glass fiber filter treated exactly like air samples but exposed to the sampling flow for only $0.5 \min \left(\sim 0.25 \mathrm{~m}^{3}\right.$ of air; "glass fiber sampling background") at each of the $\mathrm{PM}_{2.5}$ sampling locations (Munich, Hohenpeissenberg, Mt. Zugspitze). No blanks were available for the cellulose nitrate filter samples.

DNA was not detected on any of the glass fiber laboratory blanks, indicating that contamination could be excluded during the filter handling and extraction process in the laboratory. In contrast, up to $1 \mu \mathrm{g}$ of DNA was detected on the polypropylene supplier and tablet blanks. The polypropylene filter blank DNA could be amplified and cloned using universal bacterial primer, indicating bacterial contaminations. The sequencing reaction, however, failed and thus the exact identity of the DNA could not bet determined. Nevertheless, these findings indicate that decontamination of sampling substrates by baking at high temperature or alternative methods such as autoclaving is a necessary prerequisite for reliable molecular genetic analyses of atmospheric aerosol samples. DNA was also found on each of the glass fiber sampling background filters: urban $1.6 \mu \mathrm{g}$, rural $4.8 \mu \mathrm{g}$, high-alpine $2.4 \mu \mathrm{g}$. The urban and high-alpine background filters were lower by factors of 3-4 than the lowest values determined for real PM samples. The rural background filter, however, was as high as the lowest PM sample, although the sampled volume was smaller by a factor of $\sim 1000$. These findings indicate that the handling of filters at the beginning and end of the sampling period can be a major source of contamination and lead to high background DNA concentration levels. The composition and molecular signature of the biological 
Table 3. DNA sequences found in fine particulate matter $\left(\mathrm{PM}_{2.5}\right)$. For each of the different measured sequences (bacteria S1-S34, fungi S35S38, plants S39-S42, animals S43) information on the best-match sequences from the NCBI databank search (identity score and accession number) is given together with the organism and taxon determined by phylogenetic analysis. Additionally, the PCR primer pair used for their amplification ( $\mathrm{B}=\mathrm{Bacteria}, \mathrm{A}=\mathrm{Animal}, \mathrm{F}=$ Fungi; Table 2) is given and how often and on which filter samples the different sequences were detected. For bacteria, the lengths (number of base pairs, bp) of tentatively assigned terminal-restriction fragments (T-RF) is presented. Note that the identified sequences may have originated from viable as well as from dead cells in the investigated aerosol samples, because DNA can persist in cells after they lose their viability.

\begin{tabular}{|c|c|c|c|c|c|c|c|c|}
\hline $\begin{array}{l}\text { Sequence } \\
\text { ID }\end{array}$ & $\begin{array}{l}\text { PCR } \\
\text { Primer }\end{array}$ & $\begin{array}{l}\text { Best match } \\
\text { identity }(\%)\end{array}$ & $\begin{array}{l}\text { Best match } \\
\text { accession number }\end{array}$ & Organism & Taxon & $\begin{array}{l}\text { T-RF } \\
\text { length (bp) }\end{array}$ & $\begin{array}{l}\text { Number of } \\
\text { occurences }\end{array}$ & $\begin{array}{l}\text { Sample } \\
\text { ID }\end{array}$ \\
\hline S1 & B & 99 & DQ163939 & Bacteria & $\gamma$-Proteobacteria & 493 & 10 & U-A1, 2xU-A2, 4xU-A3, U-A-4, HA-A7, HA-A8 \\
\hline $\mathrm{S} 2$ & B & 99 & AY168595 & Bacteria & Actinobacteria & 158 & 2 & U-A1, U-A5 \\
\hline S3 & $\mathrm{B}$ & 99 & DQ163939 & Bacteria & $\gamma$-Proteobacteria & 493 & 3 & U-A1, R-A13, HA-A9 \\
\hline S4 & B & 99 & AM055711 & Bacteria & $\gamma$-Proteobacteria & 494 & 4 & U-A2, U-A3, R-A14, HA-A8 \\
\hline S5 & $\mathrm{B}$ & 99 & U87763 & Bacteria & $\alpha$-Proteobacteria & 152 & 1 & U-A2 \\
\hline S6 & B & 100 & AY642051 & Bacteria & Actinobacteria & & 1 & U-A3 \\
\hline S7 & B & 99 & DQ163939 & Bacteria & $\gamma$-Proteobacteria & 493 & 1 & $\mathrm{U}-\mathrm{A} 4$ \\
\hline S8 & B & 99 & AM055711 & Bacteria & $\gamma$-Proteobacteria & 494 & 1 & U-A4 \\
\hline S9 & B & 99 & AY053481 & Bacteria & Actinobacteria & & 1 & $\mathrm{U}-\mathrm{A} 4$ \\
\hline S10 & B & 99 & DQ279310 & Bacteria & $\gamma$-Proteobacteria & & 1 & U-A4 \\
\hline S11 & B & 99 & DQ057384 & Bacteria & $\beta$-Proteobacteria & 489 & 1 & U-A5 \\
\hline S12 & B & 99 & AF509579 & Bacteria & $\beta$-Proteobacteria & 489 & 1 & U-A5 \\
\hline S13 & B & 99 & AF509579 & Bacteria & $\beta$-Proteobacteria & 489 & 4 & U-A5, 3xR-A12 \\
\hline S14 & B & 99 & AF509579 & Bacteria & $\beta$-Proteobacteria & 489 & 1 & U-A5 \\
\hline S15 & B & 99 & DQ057384 & Bacteria & $\beta$-Proteobacteria & 489 & 1 & U-A5 \\
\hline S16 & B & 99 & AY642054 & Bacteria & Actinobacteria & 58 & 1 & $\mathrm{R}-\mathrm{A} 10$ \\
\hline S17 & B & 99 & DQ336995 & Bacteria & $\gamma$-Proteobacteria & & 1 & R-A 10 \\
\hline S18 & B & 99 & AB042289 & Bacteria & Actinobacteria & & 1 & R-A11 \\
\hline S19 & B & 99 & AE017283 & Bacteria & Actinobacteria & & 1 & R-A11 \\
\hline S 20 & B & 99 & DQ163939 & Bacteria & $\gamma$-Proteobacteria & 493 & 1 & R-A11 \\
\hline $\mathrm{S} 21$ & $\mathrm{~B}$ & 99 & AF509579 & Bacteria & $\beta$-Proteobacteria & 489 & 1 & R-A12 \\
\hline S22 & B & 99 & AY959147 & Bacteria & Firmicutes & 71 & 1 & R-A12 \\
\hline S23 & B & 99 & DQ163939 & Bacteria & $\gamma$-Proteobacteria & 493 & 1 & $\mathrm{R}-\mathrm{A} 13$ \\
\hline S24 & B & 100 & AY168586 & Bacteria & Actinobacteria & & 2 & 2xR-A14 \\
\hline S25 & B & 99 & AM055711 & Bacteria & $\gamma$-Proteobacteria & 494 & 1 & R-A14 \\
\hline S26 & B & 99 & D14506 & Bacteria & $\alpha$-Proteobacteria & & 1 & HA-A6 \\
\hline S27 & B & 99 & AF385528 & Bacteria & $\beta$-Proteobacteria & & 1 & HA-A6 \\
\hline S28 & B & 99 & AF385528 & Bacteria & $\beta$-Proteobacteria & & 1 & HA-A6 \\
\hline S29 & B & 99 & AF509579 & Bacteria & $\beta$-Proteobacteria & & 1 & HA-A7 \\
\hline S30 & B & 99 & AF385528 & Bacteria & $\beta$-Proteobacteria & & 1 & HA-A7 \\
\hline S31 & B & 99 & AM055711 & Bacteria & $\gamma$-Proteobacteria & 494 & 1 & HA-A8 \\
\hline S32 & B & 99 & AM055711 & Bacteria & $\gamma$-Proteobacteria & 494 & 1 & HA-A8 \\
\hline S33 & B & 100 & AY642054 & Bacteria & Actinobacteria & & 1 & HA-A 8 \\
\hline S34 & B & 99 & DQ163939 & Bacteria & $\gamma$-Proteobacteria & 493 & 1 & HA-A8 \\
\hline S35 & A & 99 & AF530542 & Fungi & Basidiomycota & & 1 & $\mathrm{U}-\mathrm{A} 2$ \\
\hline S36 & A & 99 & AB108787 & Fungi & Ascomycota & & 1 & U-A3 \\
\hline S37 & A & 99 & X69842 & Fungi & Ascomycota & & 1 & U-A3 \\
\hline S38 & $\mathrm{F}$ & 100 & AY463365 & Fungi & Ascomycota & & 1 & U-A4 \\
\hline S39 & A & 99 & AF206895 & Plant & Cucurbita & & 1 & U-A3 \\
\hline $\mathrm{S} 40$ & $\mathrm{~F}$ & 94 & D38246 & Plant & Pinaceae & & 1 & U-A4 \\
\hline S41 & $\mathrm{F}$ & 95 & AY 156588 & Plant & Bryophyta & & 1 & U-A4 \\
\hline $\mathrm{S} 42$ & B & 98 & AY 156592 & Plant & Bryophyta & & 1 & U-A4 \\
\hline S43 & A & 93 & L31841 & Animal & Alveolata & & 1 & U-A2 \\
\hline
\end{tabular}

material and DNA collected during this process may just be more concentrated but similar to that in the sampled air flow. On the other hand, it might also be characteristic for the sampling equipment rather than for the sampled air flow and investigated environment. In any case, analytical artifacts related to contamination of sampling materials prior to use or during sample collection and handling can strongly influence the molecular genetic analysis of atmospheric aerosols. In earlier studies, this aspect had not been addressed at all. Our results clearly demonstrate the necessity and effectiveness of material decontamination and parallel blank extractions.

\subsection{Molecular genetic analyses}

With the DNA extract from each of the filters listed in Table 1, five PCRs were performed to amplify DNA from bacteria, archaea, fungi, land plants, and animals for sequence analysis. PCR products were obtained for all categories except archaea. All PCR products were cloned, and from about 100 clones, 24 were randomly selected, lysed, and amplified separately again. Depending on the success rate of the second step of amplification, up to seven products of the 24 PCRs were sequenced. The obtained sequences were blasted in the databank of the National Center for Biotechnology 


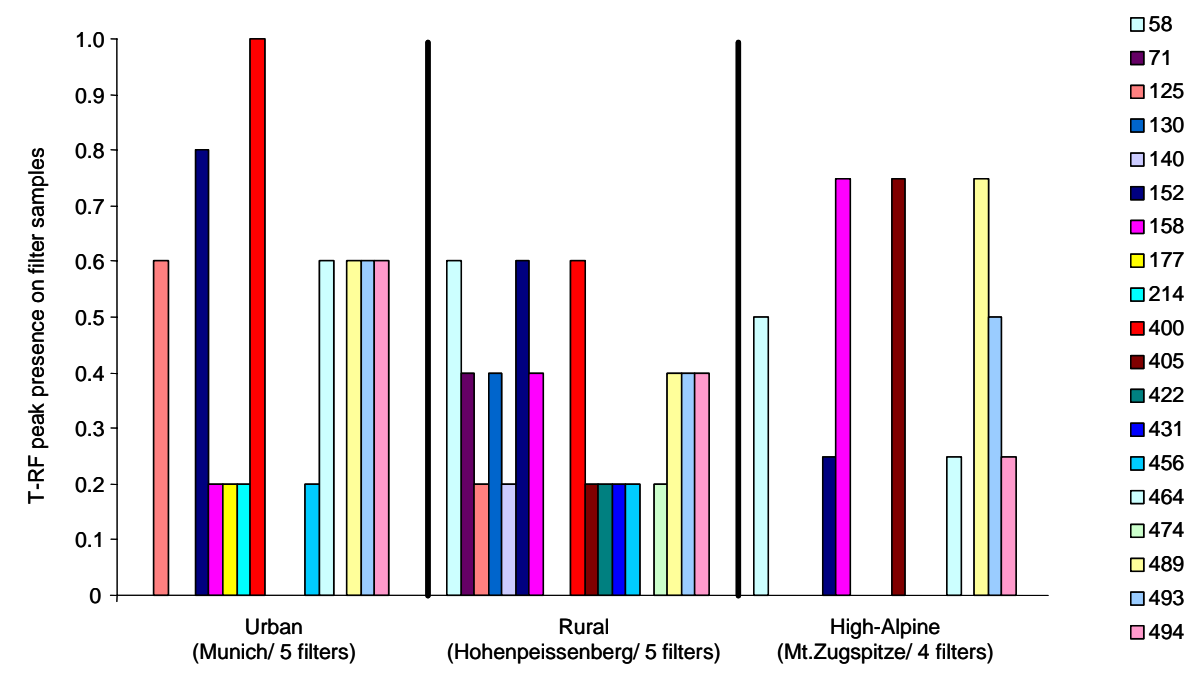

Fig. 2. Distribution of bacterial T-RF peaks among $\mathrm{PM}_{2.5}$ filter samples and locations. The $\mathrm{x}$-axis represents the different sampling locations and measured T-RF peak positions (number of base pairs, bp). The y-axis specifies the fraction of filter samples on which the T-RF peaks were found at each location. For example, the $125 \mathrm{bp}$ fragment was found in 3 of 5 filters (0.6) from Munich, in 1 of 5 filters from Hohenpeissenberg and in none of Mt. Zugspitze.

Information (NCBI) to find the closest match and determine the taxonomy of the organisms from which the DNA on the filter samples had most likely originated.

Systematic sequence analyses and complementary TRFLP investigations were performed only for the $\mathrm{PM}_{2.5}$ samples, because the filters had been decontaminated prior to use. All sequences obtained for these samples are summarized in Table 3 and discussed in Sects. 3.2.1-3.2.3. As discussed above, the TSP samples were most likely influenced by filter contaminations. Nevertheless, some characteristic results obtained for the TSP samples will be outlined in Sect. 3.2.3.

\subsubsection{Prokaryotes in $\mathrm{PM}_{2.5}$}

\section{Sequences and phylogeny}

As summarized in Table 3, 53 bacterial, but no archaeal, clone sequences could be retrieved from the investigated $\mathrm{PM}_{2.5}$ samples. For 29 sequences the taxonomic identity was determined by a databank search on NCBI.

Three sequences exhibited $100 \%$ identity with Actinobacteria, the other sequences exhibited $99 \%$ identity with different Gamma- and Betaproteobacteria. Several of the clone sequences showed best match with the same databank sequence, possibly since the clone sequences were from bacteria whose sequence had not yet been determined and entered into database or because they have been partially degraded in the air or upon sampling and analysis (e.g., chemical modification of individual base pairs).

Twenty four sequences could not be resolved by comparison with NCBI sequences, since the taxonomy of the closest matches were unclear (categorized as "environmental samples" in the databank). For taxonomic identification of these 24 sequences we performed a phylogenetic analysis by calculating a neighbor-joining tree that consisted of all 53 sequences from this study and 74 sequences from the ARB databank (Ludwig et al., 2004).

The phylogenetic analysis yielded 27 Gamma-, 13 Beta-, and 2 Alphaproteobacteria sequences, 10 Actinobacteria, and 1 Firmicute. Unlike Maron et al. (Maron et al., 2005), we found no Deltaproteobacteria in the investigated aerosol samples. Proteobacteria are one of the largest groups in the domain Bacteria. They include many pathogens as well as nitrogen oxidizing bacteria living in soils and on plants. Gammaproteobacteria are known to be particularly flexible and adaptable to different environments. Actinobacteria and Firmicutes are mostly Gram positive bacteria, many of which form spores for aerial transport. Most Actinobacteria are found in soil, where they are involved in the decomposition of organic materials. The Firmicutes include common soil bacteria like the endospore-forming bacilli such as Bacillus subtilis, which is frequently detected in soil, water and air, but also prominent pathogens like Bacillus anthracis or Bacillus thuringiensis, which is used as an agricultural insecticide. Only recently Brodie et al., 2007, have shown that endemic pathogens do occur naturally in our environment. For Gammaproteobacteria, only 13 of the 27 clone sequences were different from each other, and for the 13 different clone sequences the databank search yielded only 4 different best-match sequences (DQ163939, AM055711, DQ279310, DQ336995). For Betaproteobacteria, 10 of the 13 sequences were different from each other and the databank search yielded 3 different best-match sequences 


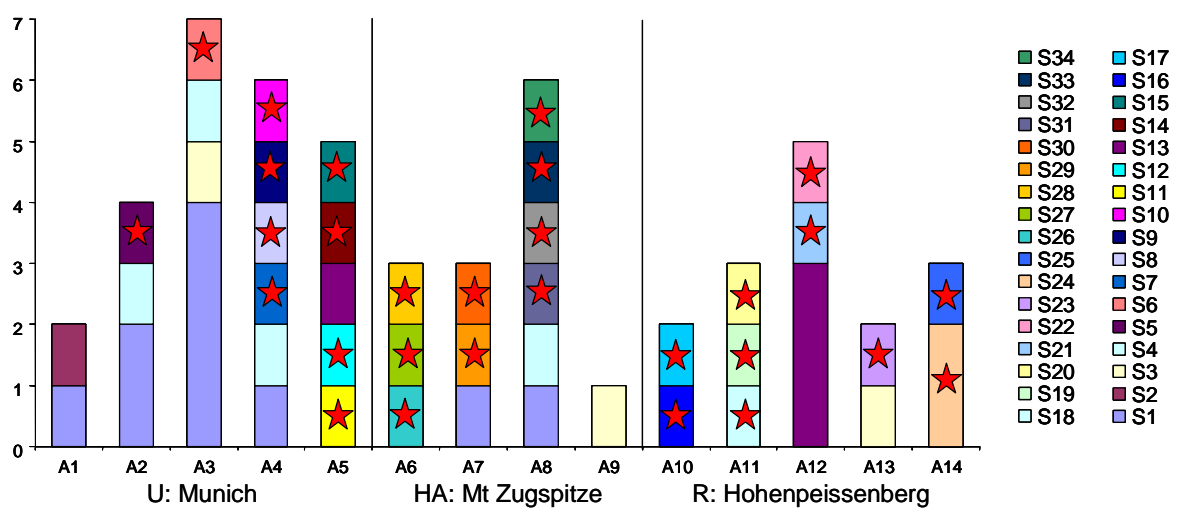

Fig. 3. Distribution of bacterial DNA sequences among $\mathrm{PM}_{2.5}$ filter samples and locations. Number and identity of measured sequences per filter sample. Different sequences (S1-S34) are illustrated in different colors. Sequences that occurred uniquely on one filter sample are highlighted with a red star.

(DQ057384, AF385528, AF509579). For Alphaproteobacteria, on the other hand, both of the clone sequences were different and yielded different best-match sequences (U87763, D14506). Also for Actinobacteria, most of the determined sequences were different from each other (8 out of 10) and yielded different best-match sequences (7).

\section{Diversity}

For characterization of the bacterial diversity, T-RFLP analyses were performed with the DNA extracts from all $\mathrm{PM}_{2.5}$ samples (Table 1). Figure 2 summarizes the number, length, and relative abundance of the 19 different T-RFs detected at the different sampling locations. The urban $\mathrm{PM}_{2.5}$ samples from Munich filters exhibited in total $11 \mathrm{~T}-\mathrm{RF}$ peaks (125-494 bp). One of the T-RF peaks (400 bp) was found in all five samples, and four were found only in one sample (Fig. 2). The rural samples from Hohenpeissenberg exhibited the highest bacterial diversity with 16 T-RF peaks (58$494 \mathrm{bp}$ ) in total; none of them in all five samples and seven only in one sample (Fig. 2). The high-alpine samples from Mt. Zugspitze exhibited the lowest diversity with eight peaks in total; none of them in all four samples and three only in one sample (Fig. 2).

To compare and connect the results of T-RFLP and clone sequence analyses, the number of base pairs until the first restriction site for Msp I "C-CGG" was determined for each of the clone sequences found in the $\mathrm{PM}_{2.5}$ samples to obtain in-silico the size of the T-RF expected from this clone. When the calculated number coincided with the length of one of the observed T-RF peaks, the sequences and T-RF peaks were tentatively assigned to each other (Table 1).

As detailed in Table 3, all of the T-RFs with a length of 489 were matching multiple Betaproteobacteria and those with a length of 493 or 494 bp were matching multiple Gammaproteobacteria sequences. The T-RFs with a length of 152 ,
158,58 , or $71 \mathrm{bp}$ were matching individual sequences of Alphaproteobacteria, Actinobacteria (TR-F 158 and 58), or Firmicutes, respectively. In total, 37 of the 44 bacterial sequences could be matched with one of the seven TR-F peaks specified above. For the other twelve T-RF peaks no tentative taxonomic assignment could be achieved, indicating that the T-RFLP analyses resolved fewer taxa than clone sequence analysis, but covered more of the bacterial diversity in the investigated samples.

As illustrated in Figs. 2 and 3, five T-RF peaks (152, 158, 489,493 , and $494 \mathrm{bp}$ ) and two of the clone sequences (S3, S4) were found at all sampling locations. Two T-RF peaks (177 and $214 \mathrm{bp}$ ) and 11 clone sequences (S2, S5-S13, S15) were found exclusively in the urban samples from Munich, six T-RF peaks $(71,130,140,422,431$, and $474 \mathrm{bp})$ and ten clone sequences (S16-S25) exclusively in the rural samples from Hohenpeissenberg. In the high-alpine samples from Mt. Zugspitze we found only T-RF peaks that were also detected in samples from the urban or rural locations. Nine of the measured sequences (S26-S34), however, were detected only in the high-alpine samples.

Shannon-Weaver diversity indices $(H)$ were calculated for each sampling location from both the number of T-RF peaks observed and the number of clone sequences determined (Table 4). Both data sets indicate the highest bacterial diversity for the rural samples from Hohenpeissenberg. The $H$ values based on the sequence data indicate similar diversities for the urban and high-alpine samples, whereas the $H$ values based on the T-RFLP data indicate higher diversity for the urban samples than for the high-alpine samples. The results are consistent with earlier observations that the concentration of PBA particles in high-alpine regions is lower than in levels directly above the sea level (Jaenicke et al., 2000). Note, however, that we have calculated the ShannonWeaver indices just as preliminary indicators for the diversities observed with the different techniques applied in this exploratory study. The calculated values should not be regarded 
Table 4. Diversity indices for bacteria detected in $\mathrm{PM}_{2.5}$ samples from different locations. Shannon-Weaver diversity indices $(H)$ and evenness $(e)$ of the data calculated from bacterial sequence and T-RFLP data. For the T-RFLP data also the range of the species richness $(S$, referring to number of T-RF peaks) for every location is given. All samples for one location were combined.

\begin{tabular}{lccccc}
\hline & \multicolumn{2}{c}{ Diversity $(H)$} & \multicolumn{2}{c}{ Evenness $(e)$} & \multicolumn{2}{c}{ Species Richness $(S)$} \\
\hline & $H(\mathrm{seq})$ & $H$ (T-RFLP) & $e($ seq) & $e$ (T-RFLP) & $S$ (T-RFLP) \\
\hline Urban (Munich) & 1.07 & 2.35 & 1.78 & 2.17 & $4-7$ \\
Rural (Hohenpeissenberg) & 1.25 & 2.6 & 2.08 & 2.13 & $4-7$ \\
High-Alpine (Zugspitze) & 1.09 & 1.98 & 1.82 & 2.19 & 4 \\
\hline
\end{tabular}

as robust parameters for further statistical analysis and interpretation. As pointed out by Blackwood et al. (2007), diversity indices calculated from T-RFLP data can be biased, and we are planning to use and compare also other indices in follow-up studies with larger data sets.

Overall, the T-RFLP analysis indicates lower species richness for our $\mathrm{PM}_{2.5}$ samples than for soil samples, for which the method had originally been developed and applied (Dunbar et al., 2000; Lüdemann et al., 2000; Lukow et al., 2000; Klamer and Hedlund, 2004; Noll et al., 2004). While in the air samples 4-7 T-RF peaks were observed per filter, in soil typically 20-30 TR-F peaks are found per sample. Note, however, that the apparent lower diversity may be partly due to chemical modification and degradation of DNA or inhibitory effects of atmospheric aerosol components on the amplification and cloning procedures. Control experiments with an urban $\mathrm{PM}_{2.5}$ sample extract have confirmed the presence of inhibitors (reduced amplification efficiency, see also 2.6).

\section{Abundances}

The best ways of estimating relative abundances of bacteria are still under discussion (Hong et al., 2006 and references therein). For the $\mathrm{PM}_{2.5}$ samples investigated in this study, the relative abundances of bacterial groups have been estimated by two approaches. One approach is based on the T-RFLP data, i.e., on normalized intensities of T-RF peaks assigned to different bacterial groups. The other approach is based on the sequence analysis data, i.e., on the numbers of sequences assigned to different bacterial groups. As detailed in Figure 4, both approaches indicate that Proteobacteria were the most abundant fraction of bacteria at all sampling locations (8795\% of T-RF peak intensities; $62-92 \%$ of sequence numbers), and that their abundance was dominated by Beta- and Gammaproteobacteria. These findings are consistent with the results of bacterial sequence analyses in air particulate matter at urban and rural locations in USA and France, respectively (Radosevich et al., 2002; Maron et al., 2005) and with most previous studies using culture-based methods (di Giorgio et al., 1996; Shaffer et al., 1997; Griffin et al., 2001).
In a very recent study, where bacteria in the air of two cities in Texas have been investigated over several weeks with chip measurement technologies rather than full sequence analyses, however, Proteobacteria were found to be less frequent than Actinomycetes, Bacteroides and Cyanobacteria (Brodie et al., 2007). The variability of atmospheric aerosol sources and composition as well as the different measurement techniques may have contributed to the different findings. Further studies are needed to determine the extent to which each of these factors influence the results. For Actinobacteria and for the individual sub-groups of Proteobacteria at the different sampling locations of this study, however, the results based on T-RFLP and sequence data were substantially different. Although sequences from Actinobacteria were found relatively often (8-32\%), the T-RFLP data indicate an abundance of only $1-3 \%$. The latter observation is consistent with recent genetic analyses of bacteria at a rural location in France (12\% in Maron et al., 2005).

We think that the abundance estimates derived from the TRFLP data are more realistic than those from the sequence data, because the latter may be biased by the cloning procedure (v. Wintzingerode et al., 1997) and are statistically not well founded due to the limited number of measured sequences.

For samples of unknown diversity it has been suggested to use about 300 sequences or more for reliable estimation of relative abundances (Kemp and Aller, 2004), whereas only 13-24 sequences were available for the different sets of $\mathrm{PM}_{2.5}$ samples investigated in this study. On the other hand, the T-RFLP analysis of $16 \mathrm{~S}$ genes as applied in this study has been reported to provide good estimates for the abundance of bacteria in soil samples (Lueders and Friedrich, 2003).

\subsubsection{Eukaryotes in $\mathrm{PM}_{2.5}$}

\section{Fungal sequences}

Four fungal sequences were detected in three of the five urban $\mathrm{PM}_{2.5}$ samples (Table 3): three sequences from Ascomycota (Cladosporium, 100\% identity with AY463365; Saccharomycetes, 99\% identity with X69842; unspecified Ascomycota, $99 \%$ identity with $\mathrm{AB} 108787$ ) and one sequence 
Seq_U (\%)
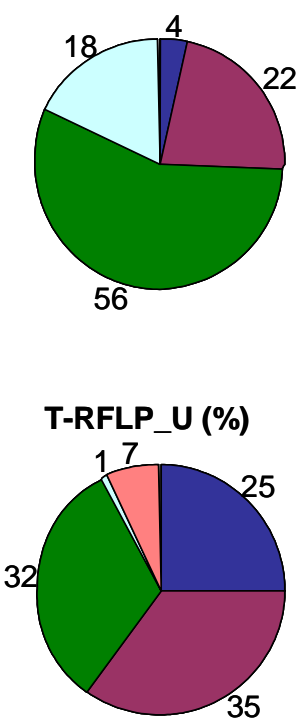

Alphaproteobacteria

Actinobacteria
Seq_R (\%)
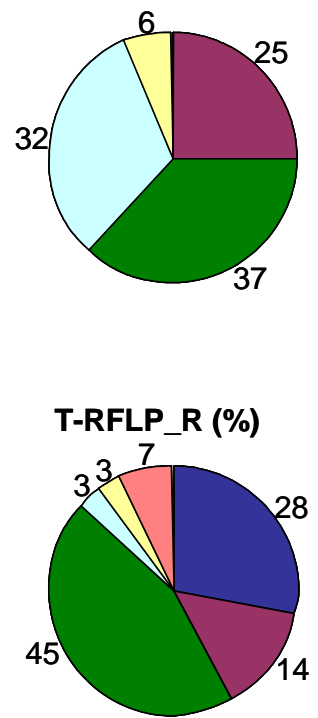

Betaproteobacteria

Firmicutes
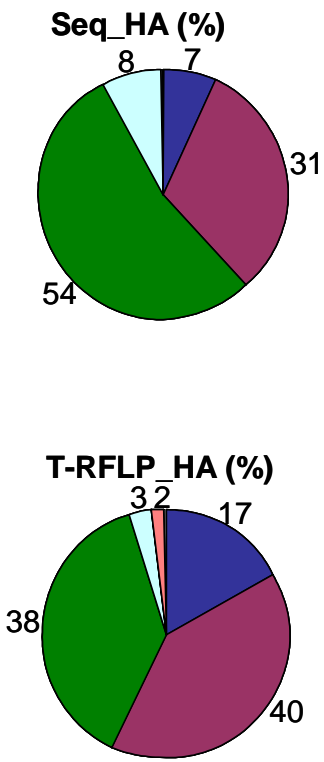

Gammaproteobacteria

Unidentified

Fig. 4. Relative abundance of bacterial groups in fine particulate matter $\left(\mathrm{PM}_{2.5}\right)$. Percentage of different bacterial groups found in $\mathrm{PM} 2.5$ samples from urban (U=urban/ Munich), rural ( $\mathrm{R}=$ rural/ Hohenpeissenberg), and high-alpine air (HA=alpine/ Zugspitze) by sequence analyses (Seq) and T-RFLP investigations. The dark colors (blue, purple, green) represent the proteobacteria, while actinobacteria, firmicutes and unidentified sequences / T-RFLPs are illustrated in light colors.

from Basidiomycota (uncultured Basidiomycetes, 99\% identity with AF530542). Ascomycota and Basidiomycota are known to actively discharge spores into the atmosphere, and their spores have been detected in a wide range of locations and concentrations (Garrison et al., 2003; Boreson et al., 2004; Griffin, 2004; Griffin and Kellogg, 2004; Elbert et al., 2006). In recent studies based on amplification of the $18 \mathrm{~S}$ gene and cultivation of fungi, Ascomycota and Basidiomycota were found to be the most abundant group accounting for proportions of 40-100\% of fungi detected in air particulate matter, (Wu et al., 2003; Boreson et al., 2004).

Spores are known to resist environmental stress and survive atmospheric transport (Griffin, 2004; Griffin and Kel$\operatorname{logg}, 2004)$, whereas DNA in fungal tissue fragments may be rapidly degraded by atmospheric photooxidants. No fungal DNA was detected in the investigated rural and high-alpine $\mathrm{PM}_{2.5}$ samples. Since fungal spores are known to be ubiquitous components of atmospheric aerosols, we think that either the applied soil DNA extraction kit was not very efficient at extracting DNA from fungal spores (Brown and Hovmoller, 2002; Boreson et al., 2004; Griffin, 2004; Griffin and Kellogg, 2004) or the amplification was inhibited. Therefore, ongoing work is aimed at the optimization of DNA extraction and amplification for fungi as well as for other eukaryotes.

\section{Plant sequences}

Four plant sequences were detected in two of the five urban $\mathrm{PM}_{2.5}$ samples, which had been collected in spring (Table 3): one sequence from a flowering plant (Angiosperm; 99\% identity with AF206895), two from mosses (Bryophytes; 95\% identity with AY156588 and 98\% with AY156592), and one from the pine family (Pinaceae; 94\% identity with D38246). The detected sequences had been amplified with the "animal" primer pair 18Sai_f / 18Sbi_r, which is specific for a region of the $18 \mathrm{~S}$ gene in the eukaryotic nuclear genome. In contrast, the land plant primer pair F1F / F1379R, which amplifies a region of the chloroplast genome, did not give any positive PCR results, although its functionality had been tested positively.

The fact that plant sequences were found only in samples collected during the pollen season in spring time, suggests that the DNA was likely recovered from pollen (angiosperm, Pinaceae) or spores (Bryophytes) rather than tissue fragments. Pollen and spores are known and designed to resist environmental stress and survive atmospheric transport, whereas DNA in plant tissue fragments may be rapidly degraded by atmospheric photooxidants. The low identity values of the Bryophyte and Pinaceae sequences may indicate that the sequences of the detected organisms have not 
yet been identified and entered into the NCBI database or that they have been partially degraded (e.g., chemical modification of individual base pairs).

All plant sequences identified in this study belong to the Viridiplantae, which were also found as the only plant category in a recent study by Boreson et al. (2004). They reported that plants accounted for $11 \%$ of the eukaryotic sequences found in a natural desert area and for $31 \%$ in urban air. In a couple of other recent studies, plants were only indirectly identified by the co-amplification of chloroplasts with bacterial primer pairs but no plant sequences were analyzed (Radosevich et al., 2002; Maron et al., 2005). In these studies the proportions of chloroplast clones were in the range of 3-32\% (Radosevich et al., 2002; Maron et al., 2005). In our study, the plant sequences account for $44 \%$ of the eukaryotic sequences detected in urban $\mathrm{PM}_{2.5}$ samples.

\section{Animal sequences}

Animal DNA was found only in an urban $\mathrm{PM}_{2.5}$ sample, and the best-match databank sequence was from a protist (Alveolata apicomplexa, $93 \%$ identity with L31841). These spore forming unicellular eukaryotes are known as common parasites of insects and vertebrates. Animal DNA is usually not protected and degrades rapidly after the death of the organism. The detected protist DNA was most likely from a spore, which is resistant like bacterial and fungal spores.

Eukaryotic sequences of animals, plants or fungi were found only in the urban $\mathrm{PM}_{2.5}$ samples from Munich although the DNA/PM ratio in these samples was smaller than in the rural and high-alpine samples (Table 3). Potential reasons are: (1) The absolute amount of DNA in the urban samples was higher. (2) The urban samples were only six months old when analyzed, whereas the rural and high-alpines samples were 2-3y old. (3) The sampling season may have played a role especially with regard to plant sequences as discussed in Sect. 3.2.2. Plant sequences. (4) The relative abundance of inhibitors reducing the extraction or amplification efficiency might have been lower in the urban samples (see also 2.6).

\subsubsection{Prokaryotes and Eukaryotes in TSP}

As outlined above, the TSP samples may have been contaminated by DNA on the sampling materials. Nevertheless, we performed test experiments with these samples and obtained the following results. In the polypropylene tablet blank we found no bacterial PCR product, and the bacterial PCR product from the polypropylene supplier blank could be cloned but not sequenced. In the TSP samples from Munich we found only six bacterial sequences of Firmicutes, which were not found in the $\mathrm{PM}_{2.5}$ samples, except for one rural sample (H-A12). In the TSP samples from Mt Zugspitze we measured 26 sequences of plant DNA from Pinaceae.

\section{Conclusions}

In this study we have demonstrated that DNA from bacteria, fungi, plants, and animals can be efficiently extracted from different types of atmospheric aerosol filter samples using a soil DNA extraction kit. The investigated samples were up to three years old and included fine and coarse air particulate matter ( $\mathrm{PM}_{2.5}$ and TSP) as well as glass fiber, cellulose nitrate, and polypropylene filter materials. Investigations of blank and background samples have shown that filter substrates have to be decontaminated prior to use. On the other hand, inhibitory effects of filter materials and of chemical components of the sampled particulate matter can reduce the efficiency of DNA amplification. In any case, the sampling, sample handling, and analytical procedures have to be carefully controlled to avoid artifacts in molecular genetic analyses of atmospheric aerosol samples.

We have combined sequencing and T-RFLP analyses and found the results to be highly complementary. The T-RFLP technique was found to resolve less, but cover more of the bacterial diversity than the sequence analysis. Both the sequence data and the T-RFLP data indicate that the bacterial diversity in the rural samples was higher than in the urban and high-alpine samples. Proteobacteria were found to be the most abundant group of bacteria in all samples. The measured sequences of fungi, plants, and animals were most likely from spores and pollen, which are known and designed to resist environmental stress and survive atmospheric transport.

Acknowledgements. We thank T. Fehrenbach, A. Hoffer, H.E. Scheel and J. Tschiersch (National Research Center) for providing filter samples and blanks; A. Häse, G. Ochs and T. Hankeln for providing test DNA; H.-J. Voss and V. Schmidt for laboratory space; H. Paulsen and M. Lohr for support and helpful discussions; C. Morris, B. Moffett, and an anonymous referee for constructive comments and suggestions. The German Research Foundation (DE1161/2-1), the LEC Geocycles Cluster in Mainz funded by the state Rheinland-Pfalz (Contribution No. 25), and the Max Planck Society (MPG) are gratefully acknowledged for funding.

Edited by: T. J. Battin

\section{References}

Ahern, H. E., Walsh, K. A., Hill, T. C. J., and Moffett, B. F.: Fluorescent pseudomonads isolated from Hebridean cloud and rain water produce biosurfactants but do not cause ice nucleation, Biogeosciences, 4, 115-124, 2007, http://www.biogeosciences.net/4/115/2007/.

Amann, R., Ludwig, W., and Schleifer, K.: Phylogenetic identification and in situ detection of individual microbial cells without cultivation, Microbiol. Rev., 59, 143-169, 1995.

Andreae, M. O., Artaxo, P., Brandao, C., Carswell, F. E., Ciccioli, P., da Costa, A. L., Culf, A. D., Esteves, J. L., Gash, J. H. C., Grace, J., Kabat, P., Lelieveld, J., Malhi, Y., Manzi, A. O., 
Meixner, F. X., Nobre, A. D., Ruivo, M. d. L. P., Silva-Dias, M. A., Stefani, P., Valentini, R., von Jouanne, J. and Waterloo, M. J.: Biogeochemical cycling of carbon, water, energy, trace gases, and aerosols in Amazonia: The LBA-EUSTACH experiments, J. Geophys. Res., 107(D20), 8066, doi:10.1029/2001JD000524, 2002.

Andreae, M. O. and Crutzen, P. J.: Atmospheric aerosols: Biogeochemical sources and role in atmospheric chemistry, Science, 276, 1052-1058, 1997.

Artaxo, P.: Size distribution of biogenic aerosol particles from the amazon basin, Atmos. Environ., 29, 393-402, 1995.

Bauer, H., Weinke, G., Schueller, E., Berger, A., Kasper-Giebl, A., Puxbaum, H., Verneylen, R., Claeys, M., and Maenhaut, W.: Contribution of bioaerosols to organic carbon in urban-fringe PM10 aerosols, European Aerosol Conference, Ghent, 2005.

Blackwood, C. B., Hudleston, D., Zak, D. R., and Buyer, J. S.: Interpreting ecological diversity indices applied to terminal restriction fragment length polymorphism data: insights from simulated microbial communities, Appl. Environ. Microb., 73, 52765283, 2007

Boreson, J., Dillner, A. M., and Peccia, J.: Correlating bioaerosol load with $\mathrm{PM}_{2.5}$ and PM10cf concentrations: a comparison between natural desert and urban-fringe aerosols, Atmos. Environ., 38, 6029-6041, 2004.

Brodie, E. L., DeSantis, T. Z., Moberg Parker, J. P., Zubietta, I. X., Piceno, Y. M., and Andersen, G. L.: Urban aerosols harbor diverse and dynamic bacterial populations, P. Natl. A. Sci., 104, 299-304, 2007.

Brown, J. K. M. and Hovmoller, M. S.: Aerial dispersal of pathogens on the global and continental scales and its impact on plant disease, Science, 297, 537-541, 2002.

Cox, C. S. and Wathes, C. M.: Bioaerosol Handbook, 1st ed, CRS Lewis Publishers, Boca Raton, Florida, p. 656, 1995.

di Giorgio, C., Krempff, A., Guiraud, H., Binder, P., Tiret, C., and Dumenil, G.: Atmospheric pollution by airborne microorganisms in the city of Marsailles, Atmos. Environ., 30, 155-160, 1996.

Dingle, A. N.: Pollen as condensation nuclei, J. recherches atmosphériques, 2, 231-237, 1966.

Dunbar, J., Ticknor, L. O., and Kuske, C. R.: Assessment of microbial diversity in four southwestern united states soils by $16 \mathrm{~S}$ rRNA gene terminal restriction fragment analysis, Appl. Environ. Microb., 66, 2943-2950, 2000.

Dusek, U., Frank, G. P., Hildebrandt, L., Curtius, J., Schneider, J., Walter, S., Chand, D., Drewnick, F., Hings, S., Jung, D., Borrmann, S., and Andreae, M. O.: Size matters more than chemistry for cloud-nucleating ability of aerosol particles, Science, 312, 1375-1378, 2006.

Elbert, W., Taylor, P. E., Andreae, M. O., and Pöschl, U.: Contribution of fungi to primary biogenic aerosols in the atmosphere: wet and dry discharged spores, carbohydrates, and inorganic ions, Atmos. Chem. Phys., 7, 4569-4588, 2007, http://www.atmos-chem-phys.net/7/4569/2007/.

Elster, J., Delmas, R. J., Petit, J.-R., and eháková, K.: Composition of microbial communities in aerosol, snow and ice samples from remote glaciated areas (Antarctica, Alps, Andes), Biogeosciences Discuss., 4, 1779-1813, 2007, http://www.biogeosciences-discuss.net/4/1779/2007/.

Fehrenbach, T.: Analyse von Aminosäuren, Proteinen und Ni- troderivaten in atmosphärischen Aerosolen und Straßenstaub, Ph.D., Technische Universität, München, 2006.

Fierer, N., Jackson, J. A., Vilgalys, R., and Jackson, R. B.: Assessment of soil microbial community structure by use of taxonspecific quantitative PCR assays, Appl. Environ. Microb., 71, 4117-4120, 2005.

Franze, T.: Analyse und Reaktivität von Proteinen in atmosphärischen Aerosolen und Entwicklung neuer Immunoassays zur Messung von Nitroproteinen, Ph.D, Technische Universität, München, 2004.

Franze, T., Weller, M. G., Niessner, R., and Pöschl, U.: Protein nitration by polluted air, Environ. Sci. Technol., 39, 1673-1678, 2005.

Fuzzi, S., M. O. Andreae, B. J. Huebert, M. Kulmala, T. C. Bond, M. Boy, S. J. Doherty, A. Guenther, M. Kanakidou, K. Kawamura, V.-M. Kerminen, U. Lohmann, L. M. Russell, and U. Pöschl: Critical assessment of the current state of scientific knowledge, terminology, and research needs concerning the role of organic aerosols in the atmosphere, climate, and global change, Atmos. Chem. Phys., 6, 2017-2038, 2006, http://www.atmos-chem-phys.net/6/2017/2006/.

Gardes, M. and Bruns, T. D.: ITS primers with enhanced specificity for basidiomycetes - application to the identification of mycorrhizae and rusts, Mol. Ecol., 2, 113-118, 1993.

Garrison, V. H., Shinn, E. A., Foreman, W. T., Griffin, D. W., Holmes, C. W., Kellogg, C. A., Majewski, M. S., Richardson, L. L., Ritchie, K. B., and Smith, G. W.: African and Asian dust: from desert soils to coral reefs, Bioscience, 53, 469-480, 2003.

Griffin, D. W.: Terrestrial microorganisms at an altitude of $20000 \mathrm{~m}$ in Earth's atmosphere, Aerobiologia, 20, 135-140, 2004.

Griffin, D.W., Garrison, V.H., Hermann, J.R., and Shinn, E.A.: African desert dust in the Caribbean atmosphere: Microbiology and public health, Aerobiologia, 17, 203-213, 2001.

Griffin, D. W. and Kellogg, C. A.: Dust storms and their impact on ocean and human health: dust in Earth's atmosphere, Ecohealth, 1, 284-295, 2004.

Großkopf, R., Janssen, P. H., and Liesack, W.: Diversity and structure of the methanogenic community in anoxic rice paddy soil microcosms as examined by cultivation and direct $16 \mathrm{~S}$ rRNA gene sequence retrieval, Appl. Environ. Microb., 64, 960-969, 1998.

Hakola, H., Tarvainen, V., Bäck, J., Ranta, H., Bonn, B., Rinne, J., and Kulmala, M.: Seasonal variation of mono- and sesquiterpene emission rates of Scots pine, Biogeosciences, 3, 93-101, 2006, http://www.biogeosciences.net/3/93/2006/.

Hamilton, W. D. and Lenton, T. M.: Spora and Gaia: How microbes fly with their clouds, Ethol. Ecol. Evol., 10, 1-16, 1998.

Hock, B., J. Schneider, S. Borrmann, R. Römpp, G. Moortgat, T. Franze, C. Schauer, U. Pöschl, C. Plass-Dülmer, and H. Berresheim: Rural continental aerosol properties and processes observed during the Hohenpeissenberg Aerosol Characterization Experiment (HAZE2002) Atmos. Chem. Phys. Discuss., 86178662, 2007.

Hong, S., Bunge, J., Jeon, S., and Epstein, S.: Predicting microbial species richness, P. Natl. A. Sci., 103, 117-122, 2006.

Höss, M., Jaruga, P., Zastawny, T. H., Dizdaroglu, M., and Pääbo, S.: DNA damage and DNA sequence retrieval from ancient tissues, Nucleic. Acid. Res., 24, 1304-1307, 1996.

Hughes, K. A., McCartney, H. A., Lachlan-Cope, T. A., and Pearce, 
D. A.: A preliminary study of airborne microbial biodiversity over Peninsular Antarctica, Cell. Mol. Biol., 50, 537-542, 2004.

Jaenicke, R.: Abundance of cellular material and proteins in the atmosphere, Science, 308, p. 73, 2005.

Jaenicke, R., Sprengard-Eichel, C., Matthias-Maser, S., and Reichert, K.: Measurements of primary biological aerosol and the soluble fraction of aerosol in remote continental area of Jungfraujoch, Switzerland, Eurotrac-2 Aerosol Annual Report, 45-49, 2000.

Kanakidou, M., Seinfeld, J. H., Pandis, S. N., Barnes, I., Dentener, F. J., Facchini, M. C., Van Dingenen, R., Ervens, B., Nenes, A., Nielsen, C. J., Swietlicki, E., Putaud, J. P., Balkanski, Y., Fuzzi, S., Horth, J., Moortgat, G. K., Winterhalter, R., Myhre, C. E. L., Tsigaridis, K., Vignati, E., Stephanou, E. G., and Wilson, J.: Organic aerosol and global climate modelling: a review, Atmos. Chem. Phys., 5, 1053-1123, 2005,

http://www.atmos-chem-phys.net/5/1053/2005/.

Kemp, P. F. and Aller, J. Y.: Bacterial diversity in aquatic and other environments: what 16S rDNA libraries can tell us, FEMS Microb. Ecol., 47, 161-177, 2004.

Klamer, M. and Hedlund, K.: Fungal diversity in set-aide agricultural soil investigated using terminal-restriction fragment length polymorphism, Soil Biol. Biochem., 36, 983-988, 2004.

Kloster, S., Feichter, J., Maier-Reimer, E., Six, K. D., Stier, P., and Wetzel, P.: DMS cycle in the marine ocean-atmosphere system a global model study, Biogeosciences, 3, 29-51, 2006, http://www.biogeosciences.net/3/29/2006/.

Kuske, C. R., Barns, S. M., Grow, C. C., Merrill, L., Dunbar, M. S., and Dunbar, J.: Environmental survey for four pathogenic bacteria and closely related species using phylogenetic and functional genes, J. Forensic. Sci., 51, 548-558, 2006.

Lindahl, T.: Instability and decay of the primary structure of DNA, Nature, 362, 709-715, 1993.

Little, D. P. and Barrington, D. S.: Major evolutionary events in the origin and diversification of the fern genus Polystichum (Dryopteridaceae), Am. J. Bot., 90, 508-514, 2003.

Liu, W. T., Marsh, T. L., Cheng, H., and Forney, L. J.: Characterization of microbial diversity by determining terminal restriction fragment length polymorphisms of genes encoding 16S rDNA, Appl. Environ. Microb., 63, 4516-4522, 1997.

Lohmann, U. and Feichter, J.: Global indirect aerosol effects: A review, Atmos. Chem. Phys., 5, 715-737, 2005, http://www.atmos-chem-phys.net/5/715/2005/.

Lüdemann, H., Arth, I., and Liesack, W.: Spatial changes in the bacterial community structure along a vertical oxygen gradient in flooded paddy soil cores, Appl. Environ. Microb., 66, 754$762,2000$.

Ludwig, W., Strunk, O., Westram, R., Richter, L., Meier, H., Yadhukumar, B., A., Lai, T., Steppi, S., Jobb, G., Förster, W., Brettske, I., Gerber, S., Ginhart, A. W., Gross, O., Grumann, S., Hermann, S., Jost, R., König, A., Liss, T., Lüßmann, R., May, M., Nonhoff, B., Reichel, B., Strehlow, R., Stamatakis, A., Stuckmann, N., Vilbig, A., Lenke, M., Ludwig, T., Bode, A., and Schleifer, K.: ARB: a software environment for sequence data, Nucleic. Acid. Res., 32, 1363-1371, 2004.

Lueders, T. and Friedrich, M.: Evaluation of PCR amplification bias by terminal restriction fragment length polymorphism analysis of small-subunit rRNA and mcrA genes by using defined template mixtures of methanogenic pure cultures and soil DNA extracts,
Appl. Environ. Microb., 69, 320-326, 2003.

Lukow, T., Dunfield, P. F., and Liesack, W.: Use of the T-RFLP technique to assess spatial and temporal changes in the bacterial community structure within an agricultural soil planted with transgenic and non-transgenic potato plants, FEMS Microb. Ecol., 32, 241-247, 2000.

Maron, P., Lejon, D. P. H., Carcalho, E., Bizet, K., Lemanceau, P., Ranjard, L., and Mougel, C.: Assessing genetic structure and diversity of airborne bacterial communities by DNA fingerprinting and 16S rDNA clone library, Atmos. Env., 39, 3687-3695, 2005.

Matthias-Maser, S. and Jaenicke, R.: Examination of Atmospheric Bioaerosol Particles with Radii $>0.2 \mu \mathrm{m}$, J. Aerosol Sci., 25, 1605-1613, 1994.

McFiggans, G., Artaxo, P., Baltensperger, U., Coe, H., Faccini, M. C., Feingold, G., Fuzzi, S., Gysel, M., Laaksonen, A., Lohmann, U., Mentel, T. F., Murphy, D. M., O’Dowd, C. D., Snider, J. R., and Weingartner, E.: The effect of physical and chemical aerosol properties on warm cloud tropics, Atmos. Chem. Phys., 6, 25932649, 2006,

http://www.atmos-chem-phys.net/6/2593/2006/.

Mikhailov, E., Vlasenko, S., Niessner, R., and Pöschl, U.: Interaction of aerosol particles composed of protein and salts with water vapor: hygroscopic growth and microstructural rearrangement, Atmos. Chem. Phys., 4, 323-350, 2004, http://www.atmos-chem-phys.net/4/323/2004/.

Möhler, O., DeMott, P. J., Vali, G., and Levin, Z.: Microbiology and atmospheric processes: the role of biological particles in cloud physics, Biogeosciences Discuss., 4, 2559-2591, 2007, http://www.biogeosciences-discuss.net/4/2559/2007/.

Noll, M., Matthles, D., Frenzel, P., Derakshan, M. and Liesack, W.: Succession of bacterial community structure and diversity in a paddy soil oxygen gradient, Environ. Microbiol., 7, 392-395, 2004.

Nowoisky, J.: Klonierung und heterologe Expression einer Xanthophyll-Deepoxidase aus der Kieselalge Phaedactylum triconutum, Diploma, Johannes-Gutenberg Universität, Mainz, 2005.

Pääbo, S.: Ancient DNA extraction, characterization, molecular cloning, and enzymatic amplification, P. Natl. A. Sci., 86, 19391943, 1989.

Pääbo, S., Poinar, H., Serre, D., Jaenicke-Després, V., Hebler, J., Rohland, N., Kuch, M., Krause, J., Vigilant, L., and Hofreiter, M.: Genetic analysis from ancient DNA, Annu. Rev. Genet., 38, 645-679, 2004.

Pöschl, U.: Atmospheric aerosols: composition, transformation, climate and health effects, Angew. Chem. Int. Edit., 44, 75207540, 2005.

Pruppacher, H. R. and Klett, J. D.: Microphysics of clouds and precipitation, Kluwer, Dordrecht, 1997.

Radosevich, J. L., Wilson, W. J., Shinn, J. H., DeSantis, T. Z., and Andersen, G. L.: Development of a high-volume aerosol collection system for the identification of air-borne micro-organisms, Lett. Appl. Microbiol., 34, 162-167, 2002.

Schauer, C., Niessner, R., and Pöschl, U.: Analysis of nitrated polycyclic aromatic hydrocarbons by liquid chromatography with fluorescence and mass spectrometry detection: air particulate matter, soot, and reaction product studies, Anal. Bioanal. Chem., 378, 725-736, 2004.

Schnell, R. G. and Vali, G.: Atmospheric ice nuclei from decom- 
posing vegetation, Nature, 236, 163-165, 1972.

Shaffer, B.T. and Lighthart, B.: Survey of culturable airborne bacteria at four diverse locations in Oregon: urban, rural, forest, and coastal, Microb. Ecol., 34, 167-177, 1997.

Simoneit, B. R. T. and Mazurek, M. A.: Organic-matter of the troposphere. 2. Natural background of biogenic lipid matter in aerosols over the rural western United-States, Atmos. Environ., 16, 2139-2159, 1982.

Smith, C. I., Chamberlain, A. T., Riley, M. S., Cooper, A., Stringer, C. B. and Collins, M. J.: Neanderthal DNA: not just old but old and cold?, Nature, 410, 771-772, 2001.

Sun, J. and Ariya, P. A.: Atmospheric organic and bio-aerosols as cloud condensation nuclei $(\mathrm{CCN})$ : A review, Atmos. Chem. Phys., 40, 795-820, 2006,

http://www.atmos-chem-phys.net/40/795/2006/.

Taylor, P. E. and Jonsson, H.: Thunderstorm asthma, Curr. Allergy. Asthm. R., 4, 409-413, 2004.

Vilgalys, R. and Hester, M.: Rapid genetic identification and mapping of enzymatically amplified ribosomal DNA from several Cryptococcus species, J. Bacteriol., 172, 4238-4246, 1990.

Voet, D. and Voet, J. G.: Biochemistry, John Wiley and Sons INC., New York, 1995.

von Wintzingerode, F., Göbel, U.B., Stackbrandt, E.: Determination of microbial diversity in environmental samples: pitfalls of PCRbased rRNA analysis, FEMS Microbiol. Rev., 21, 213-229, 1997
Weisburg, W. G., Barns, S. M., Pelletier, D. A., and Lane, D. J.: 16S ribosomal DNA amplification for phylogenetic study, J. Bacteriol., 173, 697-703, 1991.

Whiting, M. F., Carpenter, J. C., Wheeler, Q. D., and Wheeler, W. C.: The Stresiptera problem: phylogeny of the holometabolous insect orders inferred from $18 \mathrm{~S}$ and $28 \mathrm{~S}$ ribosomal DNA sequences and morphology, Syst. Biol., 46, 1-68, 1997.

Wu, Z., Tsumura, Y., Blomquist, G., and Wang, X.: 18S rRNA gene variation among common airborne fungi, and development of specific oligonucleotide probes for the detection of fungal spores, Appl. Environ. Microbiol., 69, 5389-5397, 2003.

Zhang, S., Hou, S., Ma, X., Qin, D., and Chen, T.: Culturable bacteria in Himalayan glacial ice in response to atmospheric circulation, Biogeosciences, 4, 1-9, 2007, http://www.biogeosciences.net/4/1/2007/. 